\title{
To make Florida answer to its name: John Ellis, Bernard Romans and the Atlantic science of British West Florida
}

\author{
KATHLEEN S. MURPHY*
}

\begin{abstract}
As the royal agent for British West Florida and an avid naturalist, John Ellis, FRS, took a keen interest in both the scientific and the commercial potential of the nascent colony. This article explores how Ellis and his West Floridian correspondent Bernard Romans illuminate the social and material practices of colonial science. In particular, it builds on recent scholarship to argue that new natural knowledge about West Florida did not simply circulate in the Atlantic World, but was in fact engendered by the movement of objects and ideas through the many circuits of transatlantic natural history and imperial administration. Foregrounding the Atlantic nature of such knowledge also raises questions about the limits of the categories of centre and periphery so frequently employed by historians of colonial science. Colonists such as Romans understood London to be just one centre amongst many and asserted their own epistemological claims, despite the asymmetries of power inherent to colonial science.
\end{abstract}

In 1764 the British naturalist John Ellis (c.1710-1776) was appointed to the relatively minor administrative post of royal agent for West Florida. News of his appointment prompted an effusive reply from the Swedish taxonomist Carolus Linnaeus. The Swede declared that he 'rejoice[d] with all [his] soul' and predicted that 'Florida cannot fail, under your auspices, to yield a rich harvest to the learned world. Its lot is peculiary fortunate, in being subject to your controul, and Florida may now truly answer to its name'. As a new addition to the British Empire and a place little explored by European naturalists, West Florida promised previously unknown species, vital for Linnaeus's taxonomic project. As he explained to Ellis, 'We know but few of its vegetable productions, and scarcely any thing of its animals. Fate has reserved them for you. May God grant you life and happiness, till you have laid open many of these treasures of science!' For Linnaeus, Ellis's new position promised a 'rich harvest' of Floridian flora and fauna worthy of the colony's name. Like many metropolitan naturalists, Linnaeus eagerly anticipated the natural wonders still undiscovered in the colonial periphery.

\footnotetext{
* History Department, California Polytechnic State University, San Luis Obispo, CA 93407, USA. Email: ksmurphy@calpoly.edu.

This essay was originally presented at the The Royal Society and the British Atlantic conference sponsored by the Royal Society of London in September 2010. I am grateful to Joyce Chaplin and Mordechai Feingold for inviting me to participate, and to the Royal Society, especially Keith Moore and Felicity Henderson, for sponsoring the event. I thank them and the other conference participants for their questions and suggestions. I would also like to thank the anonymous reviewers for BJHS, Regulus Allen, Lewis Call, Caroline Cornell, Christina Firpo, Jane Lehr, Molly Loberg, Devin Kuhn, Thomas Trice, members of the Johns Hopkins Early American research seminar and especially Philip Morgan for comments on previous versions of this paper.
} 
Yet Ellis never visited West Florida, nor did he intend to do so. While the royal agency put the colony under Ellis's 'controul', it also required his presence in London. ${ }^{1}$

Ellis shared Linnaeus's desire to study the natural treasures of West Florida. For Ellis, making Florida answer to its name required more than revealing its natural productions to the learned world. It also demanded that the colony's natural resources be harnessed to enrich the nascent colony and the empire as a whole. As both a naturalist and an imperial official, Ellis sought to use natural history to realize the scientific and commercial potential of the colony. His dual efforts reflected the thoroughly entangled development of science and imperialism in the early modern world. ${ }^{2}$

When Linnaeus prophesied that Ellis would make prodigious natural-historical discoveries, he did not imagine that the naturalist would personally collect specimens in the new colony; rather, that as royal agent Ellis would be the primary recipient of West Floridian seeds, specimens and observations. Linnaeus's description of Ellis overseeing the discovery of West Floridian nature from London would seem to reflect a Latourian model of colonial science. By virtue of Ellis's position as royal agent, membership in the Royal Society of London, and importance within networks of European naturalists, he would become a 'centre of calculation', codifying and authorizing natural knowledge from West Florida. His role as royal agent, in particular, would give him the ability to act at a distance and discipline the actions of others. ${ }^{3}$ Ellis's correspondence, however, tells a slightly different story. It reveals a polycentric network of exchange, albeit one in which Ellis represented an important centre for West Floridian specimens. Ellis's centrality resulted not from geography but from the social power attendant on his position as royal agent. ${ }^{4}$ This article joins with recent scholarship in the history of science to suggest the

1 Carolus Linnaeus to John Ellis, 12 February 1765 and 15 August 1765, in James Edward Smith (ed.), A Selection of the Correspondence of Linnaeus, and other Naturalists, from the Original Manuscripts, 2 vols., London, 1821, vol. 1, pp. 164, 169. Although Linnaeus invoked the colony's name to suggest abundant flora and fauna, the name originated with the Spanish explorer Juan Ponce de León, who named the region 'La Florida' ('flowery land') both for its lush vegetation and to commemorate encountering the peninsula in 1513 during Pascua Florida ('Flowery Easter'). George R. Fairbanks, History of Florida, Philadelphia: J.B. Lippincott \& Co., 1871, pp. 2-3; George R. Stewart, Names on the Land: A Historical Account of Place-Naming in the United States, Boston: Houghton Mifflin, 1967, pp. 11-12.

2 The reciprocal relationship between science and empire has been a major theme in recent scholarship on colonial science. For a start see Antonio Barrera-Osorio, Experiencing Nature: The Spanish American Empire and the Early Scientific Revolution, Austin: University of Texas Press, 2006; Richard Drayton, Nature's Government: Science, Imperial Britain, and the 'Improvement' of the World, New Haven: Yale University Press, 2000; Drayton, 'Knowledge and Empire', in P.J. Marshall (ed.), The Oxford History of the British Empire, vol. 2: The Eighteenth Century, Oxford: Oxford University Press, 1999, pp. 231-252; John Gascoigne, Science in the Service of Empire: Joseph Banks, the British State and the Uses of Science in the Age of Revolution, Cambridge: Cambridge University Press, 1998; Roy MacLeod, 'Introduction', in Nature and Empire: Science and the Colonial Enterprise, Osiris (2000) 15, pp. 1-13; James McClellan III, Colonialism and Science: Saint Domingue in the Old Regime, Baltimore: Johns Hopkins University Press, 1992; Mary Louise Pratt, Imperial Eyes: Travel Writing and Transculturation, London: Routledge, 1992; Londa Schiebinger and Claudia Swan (eds.), Colonial Botany: Science, Commerce, and Politics in the Early Modern World, Philadelphia: University of Pennsylvania Press, 2007.

3 Bruno Latour, Science in Action: How to Follow Scientists and Engineers through Society, Cambridge, MA: Harvard University Press, 1987, pp. 215-257.

4 Recent scholarship on locality and science suggests that centrality is not a matter of geography but of social identities and power relations. David Wade Chambers and Richard Gillespie, 'Locality in the history of science: 
need to replace the centre-periphery dichotomy with a polycentric latticework of exchange. ${ }^{5}$ Further, while Ellis enjoyed a broad correspondence with and some degree of influence among West Floridian colonists, his control over their actions-as he frequently complained - was at best haphazard, even if he aspired to greater control. ${ }^{6}$

The movement of ideas, objects and individuals is a concern common to historians both of science and of the Atlantic World. Atlantic historians argue that such movement represented one of the defining features of the early modern Atlantic and created the distinctive societies that populated its shores. Yet as two prominent Atlantic historians recently pointed out, there has been much less work on the circulation of ideas, relative to the rich literature on the movement of people and goods. ${ }^{7}$ In contrast, the movement of ideas has animated a robust body of scholarship in the history of science since at least the late 1960s, when George Basalla offered his much-critiqued diffusion model to explain the development of colonial science. ${ }^{8}$ Although rightly criticized, Basalla's work inspired other scholars to examine the global movement of scientific knowledge.

colonial science, technoscience, and indigenous knowledge', Osiris (2000) 2nd series, 15, pp. 223-224; Sverker Sörlin, 'National and international aspects of cross-boundary science: scientific travel in the 18th century', in Elizabeth Crawford, Terry Shinn and Sverker Sörlin (eds.), Denationalizing Science: The Contexts of International Scientific Practice, Dordrecht: Kluwer, 1993, pp. 43-72, 45.

5 Marcelo Aranda et al., 'The history of Atlantic science: collective reflections from the 2009 Harvard seminar on Atlantic history', Atlantic Studies (2010) 7, pp. 493-509, 499-503; Chambers and Gillespie, op. cit. (4), p. 223; James Delbourgo and Nicholas Dew (eds.), Science and Empire in the Atlantic World, New York: Routledge, 2008, especially 'Introduction', pp. 10-12; Savithri Preetha Nair, 'Native collecting and natural knowledge (1798-1832): Raja Sefoji II of Tanjore as a "centre of calculation", Journal of the Royal Asiatic Society (2005) Series 3, 15, pp. 279-302; Londa Schiebinger, 'Scientific exchange in the eighteenthcentury Atlantic world', in Bernard Bailyn and Patricia L. Denault (eds.), Soundings in Atlantic History: Latent Structures and Intellectual Currents, 1500-1825, Cambridge, MA: Harvard University Press, 2009, pp. 322, 328; Mary Terrall, 'Following insects around: tools and techniques of eighteenth-century natural history', BJHS (2010) 43, pp. 573-588.

6 I am indebted here to Mary Terrall's study of Réaumur, which suggests a model of science both more complicated and less systematic than the Latourian model would predict. Terrall, op. cit. (5), especially pp. 574-575.

7 Jack P. Greene and Philip D. Morgan, 'Introduction: the present state of Atlantic history', in Greene and Morgan, Atlantic History: A Critical Appraisal, Oxford: Oxford University Press, 2009, pp. 14-15. Although small in comparison with other subfields within Atlantic history, the history of Atlantic science is a dynamic and growing field. For a start see Barrera-Osorio, op. cit. (2); Jorge Cañizares-Esguerra, Nature, Empire, and Nation: Explorations of the History of Science in the Iberian World, Stanford: Stanford University Press, 2006; Joyce Chaplin, Subject Matter: Technology, the Body, and Science on the Anglo-American Frontier, 15001676, Cambridge, MA: Harvard University Press, 2001; Delbourgo and Dew, op. cit. (5); James Delbourgo, A Most Amazing Scene of Wonders, Cambridge, MA: Harvard University Press, 2006; Delbourgo, 'Slavery in the cabinet of curiosities: Hans Sloanes' Atlantic world', British Museum Website, 2007, available at www. britishmuseum.org/pdf/delbourgo \%20essay.pdf; Susan Scott Parrish, American Curiosity: Cultures of Natural History in the Colonial British Atlantic World, Chapel Hill: University of North Carolina Press, 2006; Neil Safier, Measuring the New World: Enlightenment Science and South America, Chicago: The University of Chicago Press, 2008; Londa Schiebinger, Plants and Empire: Colonial Bioprospecting in the Atlantic World, Cambridge, MA: Harvard University Press, 2004.

8 George Basalla, 'The spread of western science', Science (5 May 1967) 156(5), pp. 611-622. For an early and influential critique of Basalla's model see Roy Macleod, 'On visiting the "moving metropolis": reflections on the architecture of imperial science', in Nathan Reingold and Marc Rothenberg (eds.), Scientific Colonialism: A Cross-cultural Comparison, Washington, DC: Smithsonian Institution Press, 1987, pp. 217-249. 
Simultaneously, the rise of a constructivist approach by the late 1980s, with its assumption that all scientific knowledge is created locally, raised the question of how knowledge moved beyond its immediate locality. More recent work highlights how 'local meanings and settings interacted with knowledge circulating ... resulting in reconfigured knowledge forms or practices'. This article draws upon this idea of the 'mutational aspect of circulation' to understand the production of new natural knowledge in the British Atlantic. ${ }^{9}$ Knowledge about West Florida was not reached in London and then transported across the Atlantic wholesale (nor reached in Pensacola and then conveyed to England), but created in an iterative fashion through the movement of objects and ideas in the transatlantic circuits of natural history and imperial administration.

By telling the oft-forgotten story of British West Florida, this article demonstrates how the dynamic process of transatlantic exchange produced new natural knowledge. It begins by considering the commercial, imperial and scientific networks connecting Ellis and West Florida. Next, it examines a few of Ellis's attempts to diversify the West Floridian economy without leaving London. The naturalist assumed that those in the centre were best positioned to promote the colony's development. Yet, as the article's final section reveals, West Floridian colonials such as Bernard Romans challenged such an assumption. They understood London to be just one centre amongst many and asserted their own epistemological claims, despite the asymmetries of power that characterized the British Atlantic. While Romans shared Ellis's desire for the colony to realize the abundance suggested by West Florida's name, he believed that colonials need only nurture the natural resources in their midst in order for it to do so.

\section{Centring John Ellis and West Florida}

As Richard Drayton has argued, the period after the Seven Years War marked the beginning of a 'new type of alliance between science and government' within the British Empire. The 1760s witnessed crown support for 'scientific agriculture', new programmes to survey the natural resources of the realm, establish botanic gardens and sponsor voyages of exploration. Most of the historical literature on the emerging state sponsorship of science in Britain during the late eighteenth century has understandably focused on Joseph Banks. John Ellis's appointment as royal agent for West Florida in 1764 can also be seen as part of this trend. Yet unlike for Banks, it is difficult to argue that Ellis represented a 'centre of calculation' within British networks of scientific exchange. ${ }^{10}$

9 Kapil Raj, 'Introduction: circulation and locality in early modern science', BJHS (2010) 43, pp. 515-516. See also the recent special issue on 'Circulation and Locality in Early Modern Science' which Raj's essay introduced, BJHS (2010) 43, pp. 513-606; Aranda et al., op. cit. (5), pp. 495-499; Kapil Raj, Relocating Modern Science: Circulation and the Construction of Knowledge in South Asia and Europe, 1650-1900, New York: Palgrave Macmillan, 2007; Neil Safier, 'Global knowledge on the move: itineraries, Amerindian narratives, and deep histories of science', Isis (2010) 101, pp. 133-145.

10 Drayton, Nature's Government, op. cit. (2), pp. 64-81; For Banks as a 'centre of calculation' see David P. Miller, 'Joseph Banks, empire, and “centres of calculation” in late Hanoverian London', in Miller and 
Although we cannot understand Ellis as the centre for natural knowledge about West Florida, he certainly represented $a$ centre-and a very important one at that. Investigations into the colony's natural resources and collections of unknown flora and fauna served both scientific and imperial ends. The scientific agriculture which grew to prominence in Britain after 1763 promised to open new branches of trade and commerce by identifying and introducing new natural commodities. ${ }^{11}$ As West Florida's royal agent in London, Ellis was the primary node of contact between the colony and the imperial administration in London. The agent corresponded with a wide range of West Floridians, who relied on him to attend to both official business and personal favours. These correspondents often promised to make natural-historical collections on his behalf. Although Ellis's position supplied him with specimens and observations, he had little control over what he received. The naturalist also represented only one centre amongst many on both sides of the Atlantic.

When Britain acquired the Floridas as part of the peace settlement following its victory in the Seven Years War, many wondered at the wisdom of trading densely settled and prosperous colonies such as Cuba for the relative wilderness of Florida. While sparsely settled, the region was vast and therefore split into two separate colonies, East and West Florida. West Florida was not, as the name might imply, the western half of the modern American state of Florida. Rather, it referred to the thin stretch of land along the northern shore of the Gulf of Mexico between New Orleans and the Florida panhandle (Figure 1). The colony was pieced together from the lands surrounding Pensacola, ceded by Spain, and those near Mobile, ceded by France. Those who saw potential in the newly acquired territory pointed to both its climate and its location as evidence that the colony would become a valued addition to the British Empire. Contemporaries hoped that the region's semi-tropical climate would provide Britain a domestic source of natural commodities imported from the Mediterranean, the East Indies and Spanish America. West Florida's proximity to New Orleans and to the Gulf of Mexico also seemed to offer access to the officially off-limits ports of Spanish America. ${ }^{12}$

Any plans for West Florida's future hinged upon attracting settlers and protecting the colony from imperial rivals. In West Florida and three other strategically important but vulnerable and undeveloped colonies, Parliament took the unusual step of paying expenses normally funded through local taxes. Parliament paid to build West Florida's bridges, maintain its ferries, support its poor, and compensate its ministers and schoolmasters. As the royal agent for West Florida, Ellis worked for the crown as a comptroller overseeing from London the disbursement of parliamentary funds.

P.H. Reill (eds.), Visions of Empire: Voyages, Botany, and Representations of Nature, Cambridge: Cambridge University Press, 1996, pp. 21-37.

11 Drayton, Nature's Government, op. cit. (2), p. 79.

12 Robin F.A. Fabel, The Economy of British West Florida, 1763-1783, Tuscaloosa: University of Alabama Press, 1988, pp. 1-5, 75-109; Cecil Johnson, British West Florida, New Haven: Yale University Press, 1943, pp. 1-3, 13-24, 43-45; Robert J. Malone, 'The two Williams: science and connections in West Florida', in Kathryn E. Holland Braund and Charlotte M. Porter (eds.), Fields of Vision: Essays on the Travels of William Bartram, Tuscaloosa: University of Alabama Press, 2010, pp. 54-56. 


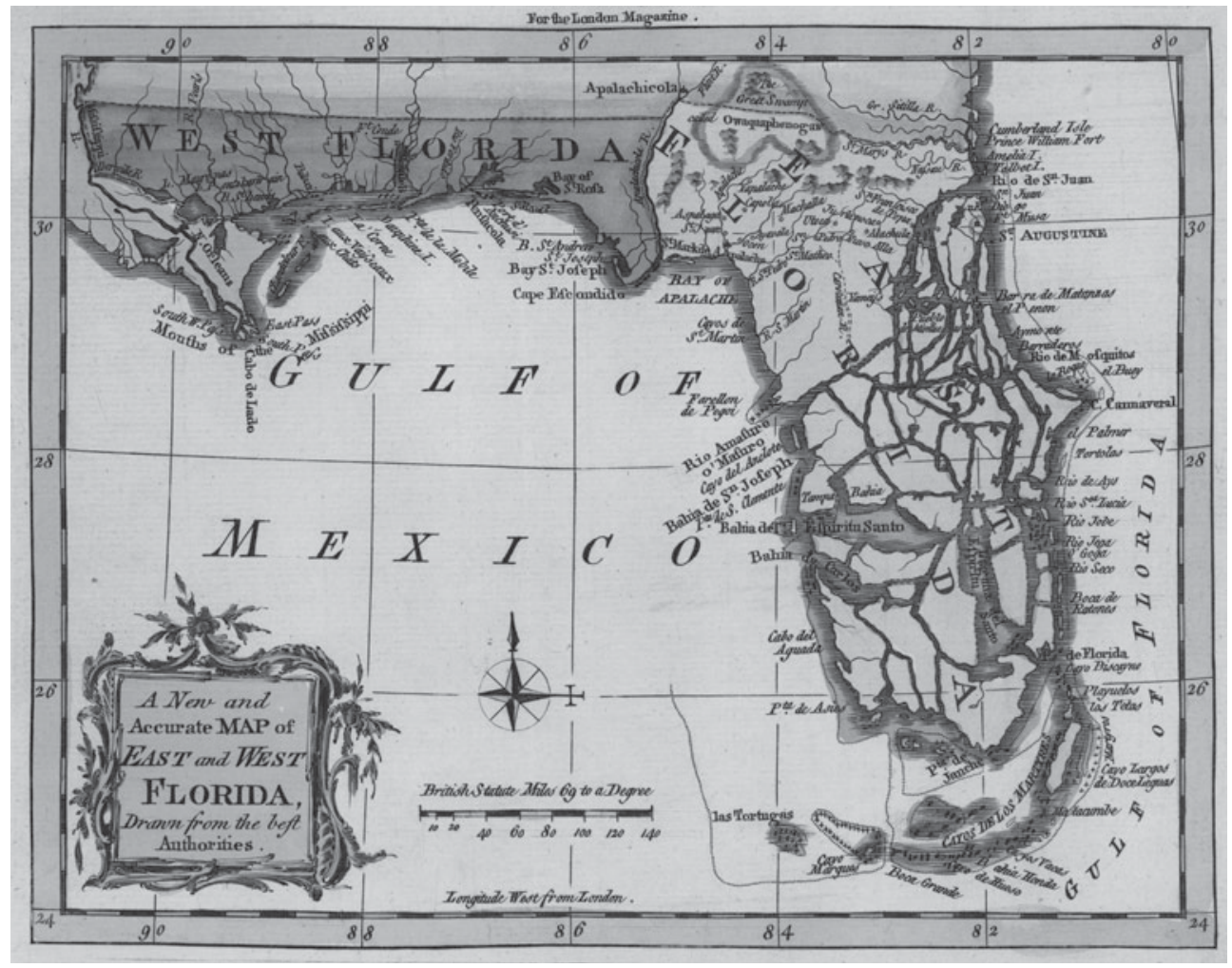

Figure 1. East and West Florida, comprising a vast region along the Gulf of Mexico, stretching from the Mississippi River to the Atlantic Ocean, were administered by the British as separate colonies following cession from France and Spain after the Seven Years War. J. Prockter, engraver, 'A new and accurate map of East and West Florida: drawn from the best authorities', in London Magazine (1765) 34, London: R. Baldwin. Courtesy of the University of South Florida Tampa Library Special \& Digital Collections.

West Floridians on the crown's payroll, from the governor to the schoolmaster, depended upon Ellis to send their salaries and reimburse their expenses. ${ }^{13}$

As Ellis declared in 1765, his 'place as King's Agent to West Florida ... entitles me to the correspondence of many gentlemen that are gone to reside there'. The naturalist's official responsibilities as royal agent put him in contact with a wide range of the colony's leading men, including a few, he thought, who were 'curious in natural history'. ${ }^{14}$

13 'John Ellis's commission as royal agent of West Florida', CO 324/53 f. 21, National Archives, Kew; Julius Groner and Robert R. Rea, 'John Ellis, king's agent, and West Florida', Florida Historical Quarterly (1988) 66 (4), pp. 385-398. While only East and West Florida, Georgia and Nova Scotia had royal agents, most British colonies had a colonial agent who worked for the colonial legislature rather than for Parliament. The colonial agent served as the colony's advocate in London, representing the colony's interests before Parliament, the ministry and other imperial officials.

14 John Ellis to Linnaeus, 1 January 1765, in Smith, A Selection of the Correspondence of Linnaeus, vol. 1, p. 163; Groner and Rea, pp. 385-398; Roy A. Rauschenberg, 'John Ellis, FRS: eighteenth-century naturalist 
As a result, his correspondence network contained more individuals in West Florida than did any other colony in British America. Most of those who sent the naturalist specimens and observations of West Floridian flora and fauna were on the imperial payroll. The chief justice William Clifton, governor Peter Chester, lieutenant governor and surveyorgeneral Elias Durnford and schoolmaster John Firby all sent Ellis packages of Floridian biota, often enclosed with letters detailing colonial affairs. ${ }^{15}$ In 1770, for example, Lt Gov. Durnford enclosed sketches, seeds and plant cuttings intended for Ellis in the dispatch box he sent to the Board of Trade. By using official channels Durnford both saved Ellis the freight cost and insured that the delicate specimens would not sit for weeks at the custom house. For Ellis and his West Floridian correspondents, the circuits of empire and science were so intertwined that it is nearly impossible to determine where the one ended and the other began. ${ }^{16}$

Requests for favours and promises of naturalia came similarly intertwined in Ellis's correspondence. Before John Blommart sailed to West Florida, he promised the naturalist that he would collect natural curiosities on his behalf. In return, Ellis pledged to help him find a place within the colonial government. During his first few years in Pensacola, Blommart sent Ellis descriptions of the colony's natural resources, shipments of curiosities and seeds and subtle reminders of the agent's promise to secure him a place 'when a new Governor may be appointed'. In this case, at least, Ellis's influence was insufficient. In 1768 the naturalist informed Blommart that he wished he had more influence with the newly appointed governor, who had awarded the position to his secretary instead. However, Ellis promised to renew his lobbying on the planter's behalf. ${ }^{17}$ While Blommart asked Ellis to use his influence with colonial officials, other correspondents put their faith in Ellis's connections at the Board of Trade. The merchant Thomas Miller of Mobile confided to Ellis in 1766 that as financial difficulties had 'at length thrown me into His Majesty's Province of West Florida', he decided to renew their previous acquaintance. The merchant promised that he 'may gratify you in some of your favourite searches after nature'. A year after renewing their correspondence, Miller travelled to London to petition the crown for a land grant of twenty thousand acres and asked Ellis to encourage the scheme. Miller hoped that the agent's influence could help him secure this vast tract of land. As royal agent, Ellis was a natural magnet for such requests, typically accompanied by promises to supply West Floridian specimens. ${ }^{18}$

and royal agent to West Florida', Notes and Records of the Royal Society of London (1978) 32, pp. 149-164; Rauschenberg, 'John Ellis, royal agent for West Florida', Florida Historical Quarterly (1983) 62, pp. 1-24.

15 Of Ellis's twenty-three correspondents in British plantation societies who sent specimens or natural historical observations, eight were in West Florida. Six of Ellis's eight correspondents in West Florida were on the imperial payroll. Kathleen S. Murphy, 'Portals of Nature: networks of natural history in eighteenth-century British plantation societies', PhD thesis, Johns Hopkins University, 2007, pp. 156-160.

16 Elias Durnford to John Ellis, 12 June 1770, vol. 1, Ellis Manuscripts, Linnean Society Archives, London.

17 John Blommart to John Ellis, 19 March 1767, Ellis Manuscripts, Linnean Society Archives, London; John Ellis to John Blommart, 14 July 1768, Ellis Notebook No 2, f. 64v, Ellis Manuscripts, Linnean Society Archives, London; John Ellis to Alexander Garden, 14 January 1770, in Smith, A Selection of the Correspondence of Linnaeus, vol. 1, p. 570.

18 Thomas Miller to John Ellis, 21 February 1766 and 16 April 1767, vol. 2, Ellis Manuscripts, Linnean Society Archives, London. 
Although Ellis received many West Floridian specimens, he was not the only important node in the overlapping circuits of imperial administration and natural history. West Floridians also frequently sent specimens to Ellis's patrons, the Secretary of State, the Earl of Hillsborough and the Lord Chancellor, the first Earl of Northington, as well as to metropolitan institutions such as the Royal Society and the royal botanic garden at Kew. West Florida's schoolmaster John Firby, for example, sent seeds of the starry anise tree and the swamp magnolia to Hillsborough and the garden at Kew in 1770. Ellis himself often shared the specimens he received with his patrons and with prominent naturalists such as Linnaeus. The previous year, when Ellis received the first starry anise seeds to reach England, he made sure that Hillsborough, Northington and Linnaeus were among the first in Europe to possess the plant. Ellis explained to Northington, 'Though your Lordship['s] gardiner never had any extraordinary kindness for Exotics I think it my duty to send you some of the produce of West Florida.' Through various trajectories, West Floridian specimens reached not just Ellis but also other minor and major centres within Europe. ${ }^{19}$

Ellis's many 'disappointments' from his West Floridian correspondents echo throughout his correspondence. Four years into his agency of the colony, Ellis counted a lost ship, a 'bad governor', another who ignored his promises to collect and a third who died suddenly among the reasons he had still not received the 'many curious seeds from thence' that he had long expected. The naturalist remained ever-optimistic, predicting that the new lieutenant governor, 'curious and intelligent in the valuable plants of that country', would prove a more satisfactory correspondent. Yet Ellis continued to complain about the 'indifferent specimens' he received, a characterization that could signify specimens that were spoiled, mislabelled, too common or simply not what he had requested. Although Ellis occasionally received the specimens he desired, this was often through happenstance, as he exerted little control over his distant correspondents. ${ }^{20}$

Ellis and his West Floridian correspondents were part of a polycentric network of exchange and circulation. Although Ellis could credit his position as royal agent for the letters and specimens he received from West Florida, it gave him no authority to determine what specimens his correspondents sent or in what condition they might arrive. Ellis continued, however, to harangue his colonial correspondents, optimistic to the end that they would send the specimens and observations he so desired. Ellis's efforts did not stop there; he also made diversification of the colonial economy a question

19 John Firby to John Ellis, 26 September 1770, Ellis Manuscripts, Linnean Society Archives, London; John Ellis to Lord Northington, draft of letter, 17 November 1769, in Spencer Savage, Catalogue of the Manuscripts in the Library of the Linnean Society of London, Part IV: Calendar of the Ellis Manuscripts, London: Linnean Society, 1948, p. 75; John Ellis to Lord Hillsborough, draft of letter, 16 November 1769, Savage, op. cit., pp. 74-75; Ellis to Linnaeus, 27 November 1769, in Smith, A Selection of the Correspondence of Linnaeus, vol. 1, p. 242. For minor and major centres within Europe see Chambers and Gillespie, op. cit. (4), p. 223; Sörlin, op. cit. (4), pp. 44-45.

20 John Ellis to Carolus Linnaeus, 19 July 1765 and 26 August 1767, in Smith, A Selection of the Correspondence of Linnaeus, vol. 1, p. 168, 211; John Ellis to the Duchess of Norfolk, 7 August 1769, in Smith, A Selection of the Correspondence of Linnaeus, vol. 2, p. 75. 
driving his own research. Through such research, Ellis strove to promote scientific agriculture while simultaneously regaining some measure of control over the unsystematic networks of exchange that connected him to West Florida.

\section{Acorns of 'some importance': experiments on seed preservation}

For contemporaries, Ellis's scientific reputation was built upon his work on zoophytes and corallines. ${ }^{21}$ Although perhaps not the first to investigate these creatures that seemed to straddle the division between plants and animals, he was arguably the most thorough in the eighteenth century. His Essay Towards a Natural History of Corallines (1755) and subsequent letters to the Royal Society established that these curious organisms were properly classified among animals. For this work, the Royal Society awarded Ellis the prestigious Copley Medal in $1768 .{ }^{22}$

Yet during the same period, Ellis pursued other lines of inquiry. While Ellis's intellectual interests were wide, economic botany looms large among them. Although this commitment to the practical application of natural history in order to identify new staple crops, investigate the uses of local plants and improve agricultural practices had long been of interest to naturalists, it took on particular prominence in Britain during the 1760 s. $^{23}$ For a natural historian who was also an imperial official, economic botany promised to further natural knowledge while benefiting the commerce of the empire. Two years after publishing his Natural History of Corallines, Ellis presented the Royal Society with the results of a series of trials that he characterized as a 'matter of some importance'. In this study Ellis turned from the taxonomic puzzle of zoophytes to the pragmatic questions of economic botany. Specifically, he turned his attention to the problem of rotting acorns.

Beginning in the late 1750 s, Ellis began to investigate how best to preserve seeds and specimens during transatlantic voyages. As someone with a wide network of correspondents in British America, Ellis knew well the damage that could be caused by salt water, natural disasters, neglect and the many other mishaps that befell specimens sent across an ocean. The immediate cause for his interest occurred in 1757 when he sent the governor of Georgia and fellow member of the Royal Society Henry Ellis acorns of the cork tree carefully packed in a box of sand. The governor reported that the acorns arrived 'intirely spoiled' by the voyage. Governor Ellis suggested that the 'hot and penetrating steams' of warm climates, combined with the 'confined air in the hold of ships', led to the seeds 'sweating or putrefactive fermentation, by which the vegetative quality ... is intirely destroyed'. The governor suggested that the problem lay in the

21 Rauschenberg, 'John Ellis, F.R.S.', op. cit. (14), pp. 149-150.

2212 November 1767, Journal Book of Scientific Meetings, Royal Society of London, pp. 35-40; 30 November 1768, Journal Book of Scientific Meetings, Royal Society of London, pp. 55-58; Rauschenberg, 'John Ellis, royal agent for West Florida', op. cit. (14), pp. 1-24; Rauschenberg, 'John Ellis, F.R.S.', op. cit. (14), pp. 149-164.

23 Drayton, Nature's Government, op. cit. (2), p. 69. 
placement of the seeds within the physical space of the ship. He therefore proposed that in the future, seeds should be sent sealed in casks placed on deck. In this way, the seeds would have the benefit of fresh air but be protected from salt water. ${ }^{24}$

With their tendency to spoil quickly, acorns were ideally suited to determine the best way to transport delicate seeds over long distances. So to test the governor's suggestion, Ellis preserved acorns seven different ways and sent them to Governor Ellis in Georgia. One group, for example, was smeared with gum arabic and wrapped in paper, another was covered in brewer's loam and a third was rolled in beeswax. All the acorns were then packed in a box of dry sand, sealed in a cask and stowed in the upper part of the ship's hold. According to Governor Ellis, those acorns preserved in beeswax or a beeswax mixture fared best. Based on this, John Ellis recommended sealing seeds in beeswax before transporting them long distances. ${ }^{25}$

John Ellis continued to pursue the question of how best to preserve seeds, and later plants, throughout the remainder of his life. A few years after his initial acorn trials, the naturalist conducted a second experiment on acorn preservation. ${ }^{26} \mathrm{He}$ noted that while acorns covered in beeswax arrived looking like they had just fallen off the tree, many of them never germinated once planted. Ellis hypothesized that the wax's heat destroyed the acorn's ability to germinate. To test this theory, he repeated his earlier experiment but this time waited to coat the acorns until the beeswax was cool but still pliable. When these acorns were cut open in front of the Royal Society in 1767 their 'appearance promised success'. To determine whether the 'vegetative quality' had indeed been preserved, Ellis sent them to William Aiton, botanic gardener at Kew. A few months later, Aiton presented the Royal Society with pots whose healthy oak seedlings testified to the success of Ellis's second series of acorn experiments. ${ }^{27}$

Ellis employed the social and scientific authority of the Royal Society and the royal botanic garden at Kew to establish that his technique was, in the words of Aiton, 'the best method that has ever been found out to preserve seeds from distant countries'. How best to preserve seeds, plants and other specimens had long been a concern of gardeners and naturalists. Typically such individuals developed material practices for preserving and transporting seeds and plants through trial and error over the course of many years. An individual's personal experience of successes and failures authorized the practices he recommended. Although Ellis participated in such networks of correspondence and exchange, his acorn experiments employed the formalized experimental culture of the Royal Society to lend epistemological authority to his technique. Even though Ellis himself was too ill to attend the meeting, the acorns were cut free of their wax casing in

24 John Ellis, 'An account of some experiments relating to the preservation of seeds: in two letters to the Right Honourable the Earl of Macclesfield, President of the Royal Society', Philosophical Transactions (1759-1760) 51, pp. 206-207.

25 Ellis, op. cit. (24), pp. 206-210.

26 John Ellis, 'A letter from John Ellis, Esquire, F.R.S., to the President, on the success of his experiments for preserving acorns for a whole year without planting them, so as to be in a state fit for vegetation, with a view to bring over some of the most valuable seeds from the East Indies', Philosophical Transactions (1768) 58, pp. 75-79; 10 March 1768, Journal Book of Scientific Meetings, Royal Society of London, pp. 478-480.

27 Ellis, op. cit. (26), pp. 75-79; 10 March 1768, Journal Book of Scientific Meetings, Royal Society of London, pp. 478-480. 
front of all those present at the Royal Society's meeting. Seven months later, the pots with oak seedlings grown by Aiton were also displayed during the society's meeting. In these ways, Ellis's acorn trials constituted a discrete event, occurring at a particular time and place and in front of credible witnesses. ${ }^{28}$

Ellis understood his acorn trials as a 'matter of some importance' sure to 'meet with the approbation of this honourable Society'. ${ }^{29}$ The inclusion of his letters regarding his acorn trials in the Philosophical Transactions in 1760 and 1768 suggests that his colleagues in the Royal Society shared such a view. A reliable way to transport seeds long distances could serve many purposes. For the avid gardeners among the members of the Royal Society, it would allow them to introduce exotic American plants into their gardens. For Ellis, however, the value of his acorn experiments lay in gardens on the other side of the Atlantic. A more reliable way to preserve seeds would facilitate the introduction of foreign botanicals into British America. If the spoil-prone acorn could be preserved, then the same method would also protect less delicate seeds during long voyages. Those particularly desired were commodities that the British 'at present' imported from 'the places of their natural growth in Europe, Asia, and Africa'. As Ellis explained,

if properly followed [these methods of preservation] may in a few years put us in possession of the most rare and valuable seeds in a vegetating state from the remotest parts of the world, which in time may answer the great end of the improvement and advancement of our trade with our American Colonies.

Colonial cultivation of foreign botanicals would not only allow Britons to purchase such commodities from their 'Brethren and Fellow Subjects' rather than 'our Enemies or Rivals in Trade', but it would also increase the demand for British manufactured goods 'and consequently our Navigation and Commerce'. ${ }^{30}$

Ellis's advice for transporting both seeds and plants reached a much broader audience with the publication of his Directions for Bringing Over Seeds and Plants, from the EastIndies and other Distant Countries in a State of Vegetation ... (Figure 2). ${ }^{31}$ While

28 Ellis, op. cit. (26), pp. 77-79; 10 March 1768, Journal Book of Scientific Meetings, Royal Society of London, pp. 478-480; Christopher M. Parsons and Kathleen S. Murphy, 'Ecosystems under sail: specimen transport in the eighteenth-century French and British Atlantics', Early American Studies (2012) 10, pp. 503-539; Peter Dear, 'Totius in verba: rhetoric and authority in the early Royal Society', Isis (1985) 76, pp. 145-161; Steven Shapin and Simon Schaffer, Leviathan and the Air-Pump: Hobbes, Boyle, and the Experimental Life, Princeton: Princeton University Press, 1985, pp. 57-59.

29 Ellis, op. cit. (24), p. 206.

30 Ellis, op. cit. (24), p. 206; Ellis, op. cit. (26), p. 78; John Ellis to Society of Arts, 2 November 1758, Guard Books, 1755-1770, IV, 11, pp. 5, 8, Archives of the Royal Society of Arts, London.

31 Within a decade, Directions was reprinted five times, including French and German editions. Although the title and accompanying material varied, Ellis's instructions for seed and plant transport set the standard for the remainder of the century. John Ellis, Directions for Bringing Over Seeds and Plants ... Together with a Catalogue of such Foreign Plants as are worthy of being encouraged in our American Colonies ... the figure and botanical description of a new sensitive plant, called Dionea musciplula: or Venus's fly-trap, London: L. Davis, 1770; Ellis, Directions for bringing over seeds and plants ..., London, 1771; Ellis, Some additional observations on the method of preserving seeds from foreign parts ..., London: W. Bowyer and J. Nichols, 1773; Ellis, A description of the mangostan and the bread-fruit ... to which are added, directions to voyagers, for bringing over these and other vegetable productions ..., London: Edward and Charles Dilly, 1775; 


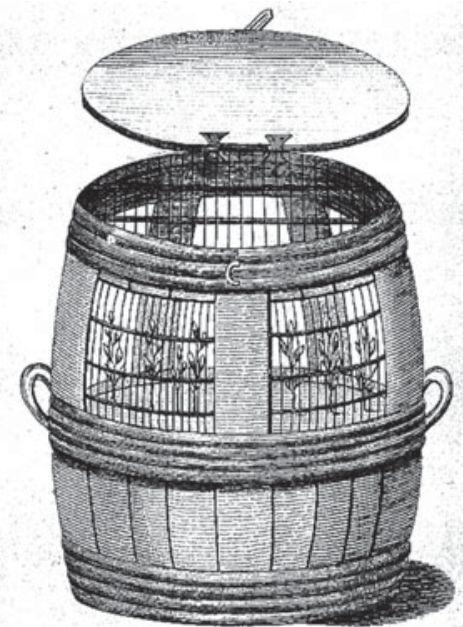

The Cosk for sonving câst India sceds with the ofenings deforited by thinc.

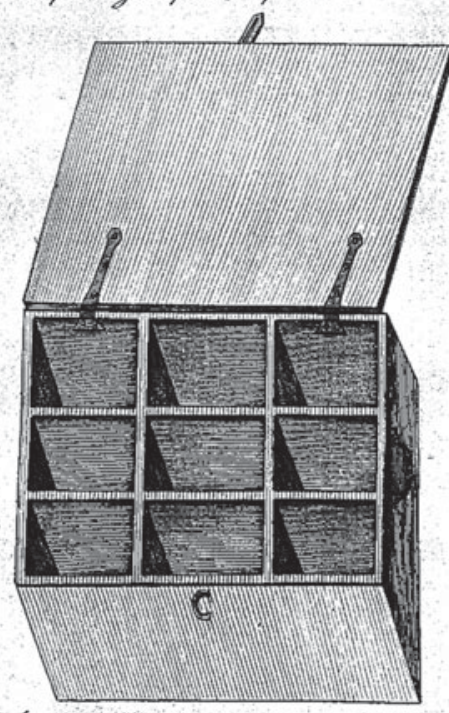

The bax with divisions for sowing different seeds in earch ss cut mofs from the sow chorn Colonies and thellat Sndies.

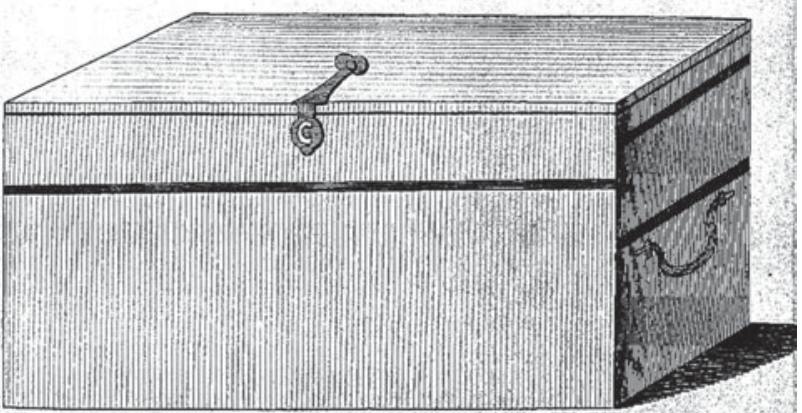

The Bow with Wat India and HiStoride flants ohut donn with the oponings at the onds and front left for fresh dir.

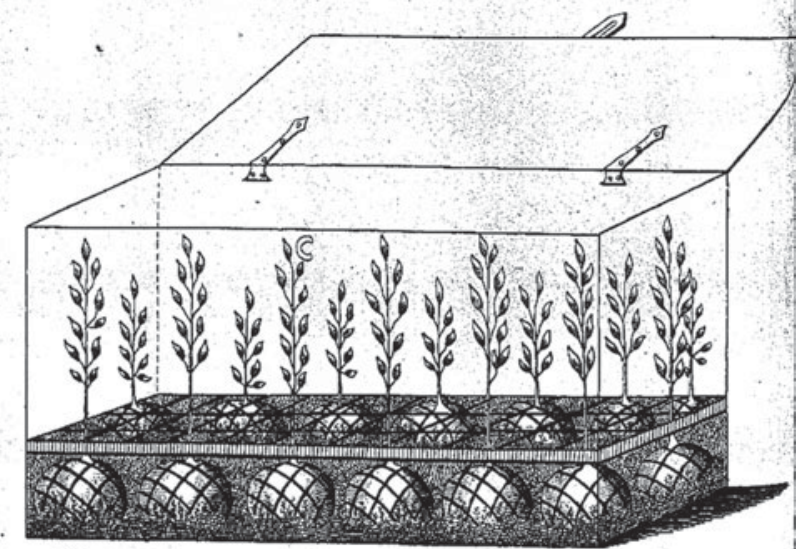

The Inside of the bax atcuving the manner of fecuring the roots of th Ftond and II India plants surrounded with earch gr mofo aid with pachethres

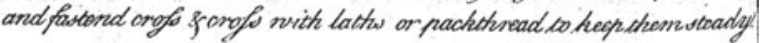

Figure 2. In Directions, Ellis recommended that ship captains and others transporting specimens from the East Indies adopt techniques perfected through his acorn trials and during decades of correspondence and exchange with American colonists. John Ellis, Directions for Bringing Over Seeds and Plants, from the East-Indies and other Distant Countries in a State of Vegetation ..., London: L. Davis, 1770, frontispiece. Courtesy of the Wellcome Library, London.

Ellis, Anweisung wie man Saamen und Pflanzen aus Ostindien und andern entlegenen Ländern frisch und grünend über See bringen kann ..., Leipzig, 1775; Ellis, Description du mangostan et du fruit à pain ... avec des instructions aux voyageurs pour le transport de ces deux fruits \& autres substances végétales ..., Rouen: P. Machuel, 1779. 
naturalists throughout Europe aspired to introduce valuable natural commodities into regions far from their natural habitat, the spoilage of seeds and plants thwarted many plans of economic botany. Yet Ellis argued that the preservation methods he developed through his acorn trials would preserve most seeds long enough to survive the journey from China to England and then on to the American colonies. For preserving plants, Ellis's exchange with West Floridians proved especially useful, 'the voyage from hence being longer ... and more attention is required to keep the plants in health, than from any other part of our North-American settlements'. The lessons learned in the Atlantic became the basis for longer-distance plant and seed transport. ${ }^{32}$

The need for Ellis's acorn trials, however, attests to the difficulty of attaining such a goal. As Ellis acknowledged, 'scarce one in fifty' of 'the great quantity and variety of seeds which we yearly receive from China ... ever comes to any thing'. In this, naturalists were at the mercy of the weather, chance and, especially, the maritime men who superintended their natural cargo during weeks or months at sea. Ellis's acorn trials were part of a broader effort to identify the material practices of preservation and transport that could partially compensate for naturalists' inability to control this critical stage in the production of knowledge. By addressing Directions explicitly to 'Captains of Ships, Sea Surgeons, and other curious Persons, who collect Seeds and Plants in distant Countries', Ellis acknowledged that unlike him, they had 'it in their Power to procure' the desired plants and supervise their transport. We can read his acorn experiments as an attempt to regain some control over this uncertain stage in the networks of circulation and exchange. While Ellis might have aspired to 'act at a distance' upon his many correspondents and collaborators, rarely did reality measure up to the desire. ${ }^{33}$

The 'great end' that Ellis saw in the improvement of colonial trade would require the mobility of plants, seeds and the knowledge necessary to cultivate them. The naturalist's work on acorns was intended to facilitate the introduction of new natural commodities into British American colonies. Movement was, in short, the object of his efforts. Yet the knowledge of how best to do so was itself produced through the varied sorts of mobility that characterized the Atlantic World. Ellis's acorn experiments were a collaborative effort, dependent upon the contributions of Governor Ellis in Georgia. And the trials themselves required the acorns to travel across the Atlantic. Although Ellis attempted to replicate the conditions of a ship's hold by placing a second set of acorns in a hot room in his London home, he never claimed this was a substitute for the conditions aboard transatlantic vessels. Rather, he suggested that the results of trials on acorns kept in London were valuable merely as an early indication of how the transatlantic set may have fared. The final conclusions of his experiments had to wait until Governor Ellis assessed the condition of the transatlantic acorns and relayed the results back to Ellis. The place where natural knowledge was produced in this case was not in Ellis's rooms in

32 Ellis, op. cit. (24), p. 214; Ellis, Directions (1770), op. cit. (31), p. 9. For the widespread interest in economic botany see Schiebinger and Swan, op. cit. (2).

33 Ellis, Directions (1770), op. cit. (31), p. 1, p. 22; Murphy, op. cit. (15), pp. 82-138; Parsons and Murphy, op. cit. (28). 
Gray's Inn or even in the halls of the Royal Society. Rather, it was produced in the circulation of specimens and ideas through transatlantic networks.

\section{'Proper experiments on the culture of ... useful plants': the imperial garden}

Ellis's acorn experiments sought to establish the best material practices for transporting delicate seeds long distances. They were premised on the belief that the 'improvement and advancement of our trade with our American colonies' required the introduction of foreign botanicals. ${ }^{34}$ But which ones? Ellis was not content to allow the migration of valuable natural commodities to be left to the whims of chance or commerce. Instead, he argued that such efforts should be overseen by metropolitan institutions.

Throughout the early modern period, travellers, ship captains and imperial officials returned to Europe accompanied by seeds and plants acquired on their travels. Simultaneously, colonists, missionaries and other Europeans in colonial spaces forwarded boxes packed with precious biocargo to European correspondents. These were the individuals Ellis had in mind who had 'it in their Power to procure' rare and valuable seeds and plants from foreign lands. Ellis sought to not only influence how they preserved this valuable cargo, but also which plants were included within it. ${ }^{35}$ Around the same time that Ellis undertook his first series of acorn experiments, the naturalist urged the Society of Arts to expand its programme of premiums to reward colonists who cultivated foreign botanicals. Ellis identified plants suitable for 'manufacture, drugs, agriculture, and the table' that could be grown in British plantation societies from South Carolina to the Caribbean. He suggested, for example, that cinnamon, nutmeg, Jesuit's bark, myrrh and mangos would thrive in the West Indies, while rhubarb, olives, figs and opium would be profitable additions to the Georgian and Carolinian economies. ${ }^{36}$ Twelve years later, Ellis revised his list of desirable foreign botanicals into an annotated catalogue to accompany his Directions. The 'Catalogue of such Foreign Plants as are worthy of being encouraged in our American Colonies' would guide travellers who sought to locate the most useful seeds and plants in foreign lands. It provided plants' Latin and English names, known uses and locations, and botanical descriptions in the second edition of Linnaeus's Species Plantarum. Taken together, Ellis's directions for transporting plants and seeds and his catalogue of useful plants sought to gain some measure of control over the often unpredictable process of introducing new natural commodities into British colonies. ${ }^{37}$

Simply identifying the most desirable plants was no guarantee that colonists would cultivate them. Ellis therefore proposed that the Society of Arts take an even more active hand. He urged the society to also use its programme of premiums to establish a 'Provincial or Publick Garden' in each of Britain's American colonies. Like the

34 Ellis, op. cit. (26), p. 78.

35 Ellis, Directions (1770), op. cit. (31), p. 22.

36 John Ellis to Society of Arts, 2 November 1758, Guard Books, 1755-1770, IV, 11, pp. 1-2, Archives of the Royal Society of Arts, London.

37 Ellis, Directions (1770), op. cit. (31), pp. 22-33. 
experimental gardens established throughout the French Empire in the 1740s, these provincial gardens would serve as sites of acclimatization, where the foreign plants identified by Ellis might be coaxed into cultivation in a new environment. 'Here then the Planter may in time observe the Experiments made without dreading the loss of his time or his Crop, here he may fix on that kind of Vegetable that is best suited to his Farm or his Fancy.' While benefiting the individual planter and the colony, these would, in Ellis's terms, be 'National experiments' designed to benefit the empire as a whole. ${ }^{38}$ Unlike the gardens supported by the French crown, however, British America's provincial gardens would remain the product of private enterprise, with members of the society underwriting the cost of the premiums. To minimize the gardens' cost, they would not function as a nursery but purely as a demonstration garden, 'to shew the Planter what kinds are likeliest to succeed best in that particular climate'. Once persuaded of the profitability of the natural commodity, the planter 'will soon find methods of procuring Seeds from his correspondents' in England. ${ }^{39}$

Ellis envisioned provincial gardens as forming a network of institutions throughout the British Empire, centrally linked through their common connection to the Society of Arts in London. Under Ellis's plan, each colony's governor and colonial council would designate land for a garden and supervise 'the proper experiments on the culture of ... useful Plants' that it would host. The Society of Arts, however, would be the gardens' ultimate arbiter. Each year, the governor and council would provide the society with a report on the state of the garden. Based on these annual reports, the society would determine what each garden should attempt to grow and would provide the seeds and plants necessary to follow its recommendations. Those at the centre could inspire colonials through the power of their example, 'When they see us labouring thus to be useful to them, that they may have it in their power to be more connected and useful to us.' Properly encouraged, provincial gardens might produce an empire both more mercantilist and more unified. ${ }^{40}$

Following the cession of West Florida, Peter Collinson, Ellis's close friend and member of both the Royal Society and the Society of Arts, advocated a similar (if more limited) garden scheme. According to Collinson, the 'Latitude, Soil and Situation of West Florida' made it, out of 'all our extensive Continent of North America', the most suited for a provincial garden, 'For in this Climate it is reasonable to conclude all the Plants that grow on either Side the Tropics, will find a genial Warmth upon their Fruits, Seeds, \&c equal to that from whence they came.' West Florida's latitude suggested that olive trees, mulberry trees (for the production of silk) and, especially, tea plants would flourish in

38 John Ellis to Society of Arts, 2 November 1758, Guard Books, 1755-1770, IV, pp. 6-7; Drayton, Nature's Government, op. cit. (2), pp. 72-79. The Society of Arts offered premiums for establishing a botanic garden in British America from 1759 until 1764. Although Drayton suggests that the society was inspired to do so by the translation of Linnaeus's Amoenitates Academicae in 1759, I believe that Ellis's proposal is the more likely explanation. Drayton, Nature's Government, op. cit. (2), p. 73.

39 Ellis hoped that in time - once the Society of Arts' 'endavours grow ripe enough'-they would attract Parliamentary support, similar to the state support scientific agriculture enjoyed in France throughout the eighteenth century. John Ellis to Society of Arts, 2 November 1758, Guard Books, 1755-1770, IV, p. 7.

40 John Ellis to Society of Arts, 2 November 1758, Guard Books, 1755-1770, IV, p. 6. 
the new colony, with a little encouragement. ${ }^{41}$ Like Ellis's proposed garden, Collinson's plan recommended a temporary use of imperial resources to jump-start economic botany in the colonies.

Ellis's acorn experiments, 'Catalogue' and provincial garden plans were based on the assumption that most desirable natural commodities would need to be imported into mainland British America. While Ellis noted that three of the plants he highlighted could be found in the British Caribbean, the remainder of the eighty-two species he described could only be found in the Mediterranean, Spanish America or the East Indies. Like Collinson, Ellis assumed that West Florida's best assets were its soil and climate, not its indigenous flora and fauna. ${ }^{42}$

Typically, economic botany took one of two forms: surveying local resources and acclimatizing foreign botanicals. Ellis's emphasis on the latter allowed him to suggest that those in the metropole were best positioned to identify the plants most suitable to be grown in the colony. Naturalists such as Ellis could use the resources at their disposal in London - for example, the premiums of the Society of Arts - to control at a distance the actions of those in the periphery. Yet the reception of such plans in West Florida suggests that colonists did not always share such an understanding of the proper division of labour within the circuits of natural history.

\section{'All the silly notions, whereby England is deceived': the view from West Florida}

At least one resident of West Florida paid careful attention to Ellis's 'Catalogue of ... Foreign Plants'. In 1772, the surveyor and cartographer Bernard Romans (c.1720c.1784) drew upon his extensive travels through East and West Florida to compose a detailed response to Ellis, entitled 'Some Observations on a Catalogue of Plants Published by John Ellis Esqure F.R.S.'. Closely following the structure of Ellis's work, Romans's 'Observations' highlighted natural commodities that might be profitably cultivated in southern British America. The surveyor suggested that many of the foreign botanicals recommended by Ellis could already be found flourishing in West Florida. ${ }^{43}$ Romans and other colonials invoked their local knowledge and personal experience to challenge the conclusions made by metropolitan naturalists such as Ellis. While they shared with him a desire to see profitable natural commodities flourish in their colony, they suggested that West Florida already contained many valuable plants. And when metropolitan naturalists challenged these conclusions, colonists looked elsewhere to support their claims.

Romans claimed that during the course of his surveying work in West Florida and neighbouring colonies, he observed more than a quarter of the plants mentioned by Ellis. Varieties of olives, cotton, palm trees, sarsaparilla, ipecacuanha and even pomegranates

41 Peter Collinson to the Society of Arts, 10 November 1763, Guard Books, 1755-1770, II, p. 70, Archives of the Royal Society of Arts, London.

42 Ellis, Directions (1770), op. cit. (31), pp. 22-33.

43 Bernard Romans to John Ellis, 13 August 1772, 'Some observations on a catalogue of plants Published by John Ellis Esqre F.R.S.', vol. 2, Ellis Manuscripts, Linnean Society, London. 
grew wild in West Florida, at least according to Romans's account. ${ }^{44}$ The surveyor noted which plants recommended by Ellis grew naturally in the region, which he had never encountered, and which had local uses unknown in England. For example, next to the names of three species of oak, Romans noted, 'In this country I have Observed 19 Species of the Oak the Suber however is not one of them. The 2 others I have reason to think may be found here. ${ }^{45}$ While Romans believed that the cork-bearing oak (Quercus suber) could not be found in West Florida, he claimed that the other two varieties recommended by Ellis grew wild in the colony. Romans reported not only that the West Floridian 'Pistachia' yielded 'abundance of Turpentine', like the species endorsed by Ellis, but that the local variety of the tree had leaves that colonists considered 'excellent food for cattle of all kinds'. For other plants listed in Ellis's 'Catalogue', Romans reported the uses he observed among local enslaved Africans and Native Americans. For example, Ellis had highlighted the paper-making properties of the Morus papyrifera, or paper mulberry tree. In response, Romans argued that West Florida was already home to several species of the Morus, and that the Choctaw and Chickasaw Indians used the bark of these trees to produce a cloth resembling linen. Based on this observation, Romans speculated that the trees' bark could also be used to make paper (Figure 3). ${ }^{46}$

As a surveyor, map-maker, planter and slave-owner, Romans brought a varied background to his natural-historical investigations. Born in the Netherlands, Romans migrated as a young man to England, where he trained as an engineer and surveyor. During the Seven Years War he came to North America to work for the crown as a surveyor and cartographer. By 1769 Romans was appointed principal deputy surveyor for the southern district of North America and owned more than a thousand acres of land and at least three slaves. ${ }^{47}$ Yet by 1772 he had nearly completed his survey work in West Florida and would soon be out of a job. Romans hoped that Ellis would use his influence in West Floridian affairs to procure him some place in the imperial administration. As he informed the London naturalist two years later, he had 'but Little Else' besides his studies of New World nature 'to recommend [him] to the attention of mankind'. He hoped that 'it may be your inclination to recommend me to some place, or business. Be it never so trifling, I will strive to shew my gratitude by close application to duty'. The following year, Romans dedicated his Concise Natural History of East and West Florida 'To John

44 Romans discussed twenty-two of the eighty-two species listed by Ellis. Although Romans's focus was on plants found in West Florida and, to a lesser degree, East Florida, he also mentioned plants he had observed in Georgia and South Carolina. Romans, op. cit. (43).

45 Romans, op. cit. (43); Ellis, Directions (1770), op. cit. (31), pp. 22-23.

46 Romans, op. cit. (43); Ellis, Directions (1770), op. cit. (31), pp. 22-24, p. 29. Romans also included these plants in his natural history of the region. Bernard Romans, A Concise Natural History of East and West Florida, New York, 1775, pp. 153 (pistachia), 154-155 (jalap), 158 (Quercus suber).

47 John D. Ware, 'The Bernard Romans-John Ellis Letters, 1772-1774', Florida Historical Quarterly (1973) 52, p. 52; Rembert W. Patrick, 'Introduction', in Bernard Romans, A Concise Natural History of East and West Florida (ed. Rembert W. Patrick), Gainesville: University of Florida Press, 1962, pp. i-xxi. 


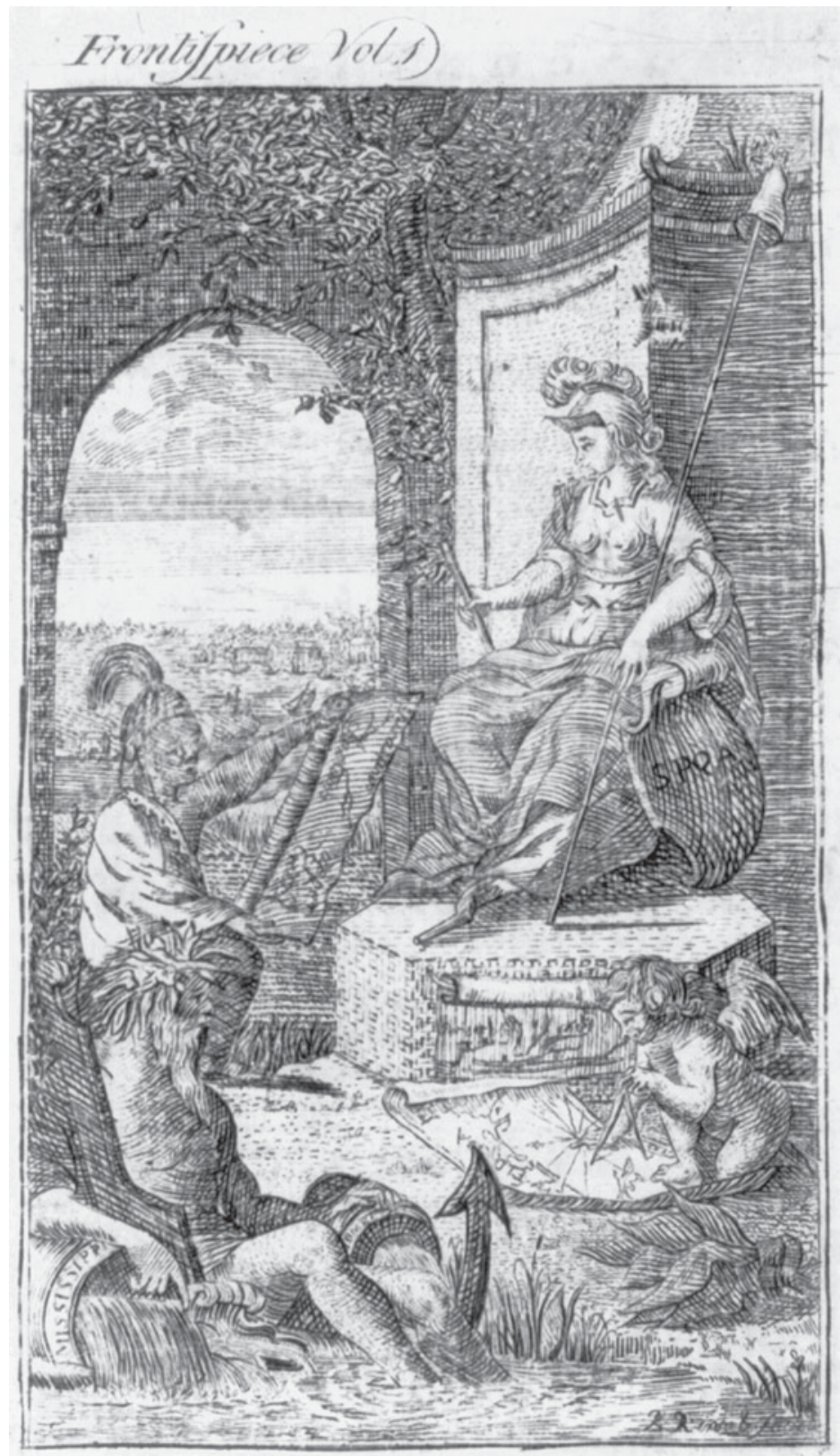

Figure 3. In the frontispiece to Romans's natural history of East and West Florida, a Native American presents Lady Liberty with a map from Romans's text, while Neptune sits beside the Mississippi River as it empties into the ocean. Romans similarly emphasized the knowledge and practices of local Indians in the 'Observations' he sent Ellis. Bernard Romans, A Concise Natural History of East and West Florida, New York, 1775, frontispiece. Courtesy of the Library of Congress, LC-USZ62-45536. 
Ellis, Esq., Fellow of the Royal Societys of London and Upsal, Agent for the Province of West Florida'. ${ }^{48}$

Romans's 'Observations' was a text operating on many levels. While it expanded upon and, in places, critiqued Ellis's 'Catalogue', it was also designed as a piece of flattery to influence a potential patron. It was accompanied by Romans's plan for a provincial garden, the directorship of which Romans implied he desired. Whereas Ellis envisioned a provincial garden for acclimatizing foreign plants, Romans assumed its purpose would be to study America flora and prepare it for transport. Romans's detailed annotations to the London naturalist's catalogue told Ellis that his text was being carefully studied in the American colonies. As Romans appropriated Ellis's text to suit his colonial context, he changed it in the process.

These changes are clear in both the form and the substance of his 'Observations'. In terms of form, Romans's text follows the basic structure of the Ellis text, with a left-hand column listing the plant's name and the far right column providing general observations such as where the plant can be found and for what it could be used. Yet Romans omitted references to Linnaeus's Species Plantarum. In place of European authorities, Romans introduced colonial ones. His text lacked any references to the standard botanical reference works, to which he very likely did not have access. Instead, he highlighted the local knowledge of West Florida's white colonists, Native Americans and enslaved Africans. ${ }^{49}$

Romans's reliance on these local authorities led him to conclude that he had discovered in West Florida a plant long desired by English naturalists and imperial officials alike. Romans claimed that he had found the valuable medicinal plant jalap growing along the Chester River near Pensacola. His initial suspicion that the jalap might be found in West Florida did not come from reading European texts. Instead, Romans's first-hand observations of how local Native Americans used the plant led him to suspect that it might be the valuable simple. ${ }^{50}$

Jalap, which hailed from the eponymous region of New Spain, was frequently used by British doctors as a cathartic. British naturalists, physicians and travellers had attempted to smuggle the simple out of the Spanish territory throughout the eighteenth century. And, as early as 1758, Ellis had recommended the introduction of the plant, which he

48 Bernard Romans to John Ellis, 14 May 1774, Ellis Manuscripts, vol. 2, p. 61, Linnean Society, London; Romans, op. cit. (47), dedicatory page. Partly through the influence of Ellis, Romans was appointed the colony's botanist, at a salary of $£ 50$ per annum. His salary, however, was revoked when he joined the Patriot side during the American Revolution.

49 Recent work on Atlantic science emphasizes the role of indigenous and African knowledge. See, for example, James Delbourgo, 'Fugitive colours: shamans' knowledge, chemical empire and Atlantic revolutions', in Simon Schaffer, Lissa Roberts, Kapil Raj and James Delbourgo (eds.), The Brokered World: Go-Betweens and Global Intelligence, 1770-1820, Sagamore Beach: Science History Publications, 2009, pp. 271-320; Kathleen S. Murphy, 'Translating the vernacular: indigenous and African knowledge in the eighteenth-century British Atlantic', Atlantic Studies (2011) 8, pp. 29-48; Susan Scott Parrish, American Curiosity: Cultures of Natural History in the Colonial British Atlantic World, Chapel Hill: University of North Carolina Press, 2006, especially pp. 22, 215-306; Schiebinger, op. cit. (7).

50 Romans, op. cit. (43); John Ellis to Society of Arts, 2 November 1758, Guard Books, 1755-1770, IV, p. 11; Romans, Concise Natural History, pp. 154-155. 
described as 'a most useful drug', into British America. ${ }^{51}$ The royal agent, however, doubted that the plant Romans had identified as jalap was indeed the same species as that sold in London apothecary shops. After examining specimens sent by Romans, Ellis speculated that it was another species of the convolvulus. While it might have similar properties, he concluded that it was not the long-desired jalap. ${ }^{52}$

Romans and other West Floridians continued to insist that the plant which could be found growing along the Chester River was the true jalap. Despite Ellis's conclusions to the contrary, Romans declared that 'samples, which I sent to divers parts of Europe and America, have proved it to be' the true jalap. Dr John Lorimer, West Florida's 'most notable intellectual', sided with Romans. In a 1772 letter to the American Philosophical Society, Lorimer argued that the Florida plant was the 'reall Jallap'. The colony's attorney general resumed the debate over jalap after Romans had left the province. Like Romans, Edmund Wegg argued that jalap was native to West Florida. If anything, he suggested that the Florida variety might be superior to the original, as it had 'all the Properties of the Spanish, without its disagreeable Flavor.' Rather than defer to Ellis's judgment on the matter, Wegg sought out other authorities to confirm his identification of the plant. Wegg reported that the samples he sent to Jamaica were 'upon Experiment ... found to be of an excellent Quality, by one of the most eminent Physicians in that Island', a Dr Pantou - so much so that the physician also wrote to request an additional thousand pounds of the drug. Similarly, Wegg argued that a surgeon's mate in the service of the Royal Navy had tested the West Florida plant and declared it to be the true jalap. Wegg appealed to the experience of these colonial medical men to support his claim. Along with this testimony, Wegg sent roots of the Florida jalap to the garden at Kew and dried samples of the plant to the Royal Society. For Wegg, this was not simply an intellectual debate. He hoped that once he had convinced members of the Royal Society of the plant's identity they would assist him in obtaining a monopoly on its export from West Florida. 53

In the eyes of Romans, the colonial authorities invoked by Wegg would have had the key advantage of first-hand experience in the region. Those who stayed home could not be trusted to fully understand this new context. The surveyor declared in his natural history that he had 'sometimes been beyond all measure vexed, and at others I have been

51 John Ellis to Society of Arts, 2 November 1758, Guard Books, 1755-1770, IV, p. 11; Ellis, Directions, op. cit. (31), p. 30; Romans, op. cit. (47), pp. 154-155. The South Sea surgeon William Houstoun smuggled a live jalap plant out of the province and transplanted it to Jamaica. However, it was destroyed by hogs after the surgeon returned to England. William Houstoun to Hans Sloane, 4 March 1731, Sloane 4052, f. 82, British Library, London; Romans, Concise Natural History, p. 154.

52 Alexander Garden to John Ellis, 15 May 1773, in Smith, A Selection of the Correspondence of Linnaeus, vol. 1, p. 596. Emma Spary's excellent essay on the identification of nutmeg illuminates the 'highly contested, complex procedure' of plant identification in a colonial context. Emma Spary, 'Of nutmegs and botanists: the colonial cultivation of botanical identity’, in Schiebinger and Swan, op. cit. (2), pp. 187-203, 187.

53 Romans, op. cit. (47), pp. 154-155; Kathryn E. Holland Braund, 'Bernard Romans: his life and works', in Holland Braund (ed.), A Concise Natural History of East and West Florida, Tuscaloosa: University of Alabama Press, 1999, pp. 1-41, 10-11; E.R. Wegg to John Ellis, 26 February 1775, vol. 2, Ellis Manuscripts, Linnean Society, London. Modern botanists agree with Ellis that the West Floridian plant is distinct from the Mexican jalap. Instead, the plant Romans discovered was most likely the cathartic wild jalap or wild potato. Braund, Concise Natural History, p. 15. 
obliged to laugh at all the silly notions, whereby England is deceived in her ideas of America'. While his conclusions about the colony's flora and fauna derived from what he had seen and experienced, he argued that these 'foolish writers' in England had 'raised some absurd hypothesis in their own brain, from whence they deduce as crooked theories as ever entered the thoughts of mankind'. ${ }^{54}$ Romans believed that his epistemological authority derived from having seen New World nature with his own eyes. While in some respects he deferred to Ellis as a potential patron, he-like Wegg-challenged the conclusions reached regarding the colony the naturalist had never seen.

Romans, Wegg and Ellis all would have agreed on the value of introducing jalap to British America and, in particular, West Florida. As Wegg declared, 'The Jalap might become a valuable article in Commerce, and instead of being furnished with it, as we now are from the Spaniards, we might supply all Europe from this Province alone. ${ }^{55}$ By supplying all of Europe - and breaking the Spanish monopoly on the drug - they would satisfy mercantilist goals of empire and the personal ambitions of West Floridian planters.

In many ways, jalap was a quintessential Atlantic natural commodity. It was a valuable export from Spanish America, the subject of botanical study throughout the Atlantic World, the object of plans for imperial gardening such as those Ellis articulated, and even the desideratum of bio-espionage, as British naturalists attempted to smuggle it out of New Spain. The contest over whether it could be found growing naturally in West Florida was equally Atlantic in character. Texts, letters, samples and live plants criss-crossed the Atlantic in an attempt to determine the identity of the Florida plant. Romans and Wegg set their local knowledge and experience against the conclusions reached by naturalists in the metropole. These competing claims, based on authorities of different sorts, circulated through the polycentric networks of natural history.

The text that sparked this debate-Ellis's 'Catalogue'-only took on its fullest meaning through its movement in the Atlantic World. Had it simply circulated in England, it would largely have failed to produce Ellis's stated objective. Ellis's recommendations were in a sense validated through its transatlantic circulation. Ellis intended his text for travellers, mariners and colonists. In Romans he found evidence that at least some among his intended audience were paying attention. Romans took seriously the idea that the eighty-two species Ellis identified would benefit the colony of West Florida and British America more generally. But he did not share Ellis's assumption that these plants would need to be imported into North America. As Romans adopted the metropolitan text to suit his colonial context, he changed it. As natural knowledge moved around the Atlantic World, the meaning and value attached to it fluctuated. Proposals hatched in London took on new resonance in the colonial context.

54 Romans, op. cit. (47), pp. 179-180.

55 E.R. Wegg to John Ellis, 26 February 1775, vol. 2, Ellis Manuscripts, Linnean Society, London. 


\section{Conclusion}

Keeping the Atlantic character of natural knowledge firmly in view helps us to evaluate some of the limitations of the centre-periphery model of colonial science. While London was surely the centre of many transatlantic networks, it was not the only centre. Its importance was a matter of perspective and dependent upon the particular situation. It remained, for example, the primary centre for patronage within the imperial administration, whether in the form of the place or position Romans desired or in Wegg's request for a jalap monopoly. Yet Wegg looked to Jamaica as well as to London for confirmation of jalap's identity. And when Romans failed to obtain the patronage he desired, he travelled to New York, Boston and Philadelphia, where he announced his intention to publish his natural history by subscription and was elected to the American Philosophical Society. ${ }^{56}$ In the transatlantic networks of exchange and circulation, Ellis represented just one centre amongst many. Through his acorn trials, 'Catalogue' and plans for provincial gardens, the naturalist sought to determine from the centre how and which specimens made the transatlantic voyage. Yet even with the social power that derived from his position as royal agent, Ellis enjoyed only limited control over the actions of his West Floridian correspondents.

The lines of centre and periphery, if strictly drawn, also make it hard to determine where many transatlantic figures fit. Take, for example, Governor Henry Ellis, John Ellis's partner in and inspiration for the acorn experiments. While he resided in Georgia in 1757 and was later appointed governor of Nova Scotia, he only lived in British America for four years. Further, he was an active member of the Royal Society and the Society of Arts. To which category does he properly belong, centre or periphery? 57

Even the geography of West Florida raises questions about how we understand centre and periphery. Much of the colony's value lay in its peripheral location. Situated on the western edge of the British Empire in the Atlantic and on the northern terminus of Spanish dominions it was doubly peripheral. Yet this marginality marked it as a potential node within transatlantic networks. Many investors in the colony hoped that West Florida would offer access to the normally off-limits ports of Spanish America. Although ultimately this did not turn out to be the case, the potential that contemporaries saw in the colony was for it to become central-or at least a centre - through its double marginality.

Whether West Florida answered to its name during its brief existence as a British colony was in the eye of the beholder. Ellis died in 1776, at the beginning of the American Revolutionary War. At that war's conclusion, Britain ceded control of the region to Spain, who had occupied it during the last years of the conflict. During the twenty years West Florida remained a British territory, it never produced a staple crop of importance and only a few previously unknown species native to the colony were

56 Bernard Romans, 'Proposals for printing by subscription, three very elegant and large maps of the navigation, to, and in, the new ceded countrie', Philadelphia, 5 August 1773, broadside, Evans 42493; Braund, op. cit. (53), p. 13.

57 Aranda et al., op. cit. (5), pp. 500-501. 
introduced to the learned world. It is unlikely that, in the opinion of Linnaeus, Florida answered to its name. For Romans, however, it always had done so. For what Romans and other colonials suggested was that rather than import natural commodities from abroad, one need only to capitalize on those that were already there. In any case, the efforts of men such as Ellis and Romans suggest that even in this most western of British American colonies, natural history remained a fully transatlantic endeavour. 